\title{
Inhibition of androgen and oestrogen production by clomiphene citrate in avian theca cells
}

\author{
R. K. O'Keefe and B. L. Marrone* \\ Department of Obstetrics/Gynecology, St Louis University School of Medicine, St Louis, \\ Missouri 63104, U.S.A.
}

\begin{abstract}
Summary. Isolated theca cells $\left(2 \times 10^{5} / \mathrm{ml}\right)$ were pre-incubated for $1 \mathrm{~h}$ in the presence or absence of clomiphene citrate $\left(10^{-12}-10^{-4} \mathrm{M}\right)$. Ovine $\mathrm{LH}(50 \mathrm{ng} / \mathrm{ml})$ was added and cells were incubated for an additional $3 \mathrm{~h}$. A $50 \%$ inhibition of $\mathrm{LH}$-stimulated androstenedione and oestrogen production was obtained with doses of $10^{-8} \mathrm{M}$ and $2 \times 10^{-7} \mathrm{M}$ clomiphene, respectively. Furthermore, the effect of clomiphene on LH-stimulated androstenedione production was reversed by washing clomiphene from the cells before stimulation with LH. In subsequent experiments, the effects of clomiphene on C17-20-lyase and aromatase activities were examined. Conversion of $\left[{ }^{3} \mathrm{H}\right] 17$-hydroxyprogesterone to androstenedione was inhibited by $50 \%$ when theca cells were pretreated with $10^{-5} \mathrm{M}$-clomiphene. In addition, conversion of testosterone to oestrogen by theca cells was inhibited in a dose-dependent manner by clomiphene, with $50 \%$ inhibition occurring at a dose of $5 \times 10^{-6} \mathrm{M}$. The results show that clomiphene treatment in vitro inhibits androgen and oestrogen production in theca cells by inhibitory effects on the activities of C17-20-lyase and aromatase. In addition to the widely-accepted effects of clomiphene on the hypothalamic-pituitary axis, the present findings add further support to the suggestion that clomiphene exerts direct effects on ovarian steroidogenesis.
\end{abstract}

\section{Introduction}

Clomiphene citrate is one of the drugs most commonly used to induce ovulation in anovulatory women. Clinical studies have demonstrated that clomiphene induces ovulation in $80 \%$ of anovulatory women, but results in only a $40 \%$ pregnancy rate (Speroff et al., 1983). The discrepancy between rates of ovulation and pregnancy has led investigators to examine the effects of clomiphene more intensely. It is generally accepted that clomiphene exhibits oestrogenic and antioestrogenic effects and induces ovulation in a complex fashion. There are believed to be 3 sites of action (Adashi, 1984). The primary site is the hypothalamus, where clomiphene blocks the negative feedback of oestrogen, thereby enhancing release of gonadotrophins. Secondary sites are the pituitary, where it enhances the GnRH-stimulated release of FSH, and the ovary, where its effects are not completely clarified.

Clomiphene inhibits progesterone synthesis in rat follicles (Laufer et al., 1982) and granulosa cells (Welsh et al., 1984), monkey luteal cells (Westfahl \& Resko, 1983) and hen granulosa cells (Sgarlata et al., 1984). In contrast, the effects of clomiphene on oestrogen biosynthesis in vitro have been less consistent. Some investigators report a stimulation (Zhuang et al., 1982; Welsh et al., 1984), and others an inhibition (Laufer et al., 1982). The effect of clomiphene on androgen synthesis has not been reported.

\footnotetext{
*Present address and address for reprint requests: Life Sciences Division, Los Alamos National Laboratory, Mail Stop-M881, Los Alamos, New Mexico 87545, U.S.A.
} 
In an effort to understand further the actions of clomiphene on ovarian steroidogenesis, we investigated the in-vitro effects of clomiphene on androgen and oestrogen production by theca cells from maturing ovarian follicles of the domestic hen. The domestic hen has only one functional ovary and ovulates daily for several consecutive days. The maturing yolk-filled follicles are arranged in a size hierarchy according to proximity to ovulation. Production of oestrogen and androgen by the preovulatory follicles occurs exclusively in the theca compartment and is influenced by LH and by the stage of follicular development. Furthermore, these cells contain C17-20-lyase (Marrone \& Hertelendy, 1985) and aromatase (Armstrong, 1984) activities. The aromatase and C17-20-lyase activities are greatest in theca cells from the follicles that are 3 and 4 days away from ovulation (Armstrong, 1984; Marrone \& Hertelendy, 1983a, b, 1985).

\section{Materials and Methods}

\section{Experimental animals}

One- to two-year-old White Leghorn hens were obtained from the University of MissouriColumbia or from Ralston Purina Farms, Gray Summit, MO. Birds selected for use in this study had regular clutches of 5 or more eggs. The time of oviposition was recorded by an automatic device. The birds were caged individually in a windowless room and kept under a $14 \mathrm{~h} \mathrm{light} / 10 \mathrm{~h}$ dark cycle. Purina Layena ration and water were provided ad libitum.

\section{Hormones and chemicals}

Ovine LH (NIADDKD-LH-22; $2 \cdot 3$ NIH-LH-SI U/mg) was a gift from the National Hormone and Pituitary Program of the National Institutes of Health. All steroids, the bovine serum albumin, soybean trypsin inhibitor, 3-isobutyl-1-methylxanthine (IBMX), and clomiphene citrate (Clomid, $67 \%$ cis, 33\% trans) were purchased from Sigma Chemical Co. (St Louis, MO). Powdered Medium 199 with Hanks' salts was purchased from Grand Island Biological Co. (New York, NY). $\left[1,2-{ }^{3} \mathrm{H}\right] 17-\mathrm{Hydroxyprogesterone} \mathrm{(sp.} \mathrm{act.} 40-60 \mathrm{Ci} / \mathrm{mmol}$ ), $\left[2,4,6,7-{ }^{3} \mathrm{H}\right]$ oestradiol-17 $\beta$ (sp. act. $90-115 \mathrm{Ci} / \mathrm{mmol}$ ), and $\left[1,2,6,7-{ }^{3} \mathrm{H}\right]$ androstenedione (sp. act. $80-115 \mathrm{Ci} / \mathrm{mmol}$ ) were obtained from New England Nuclear Corp. (Boston, MA). Baker and Fisher high-performance liquid chromatography (HPLC) solvents were used.

\section{Tissue collection and cell preparation}

Birds were killed by cervical dislocation $1-4 \mathrm{~h}$ before expected ovulation, as in previous experiments (Marrone \& Hertelendy, 1983a, b, 1985). Theca cells were obtained from the third and fourth largest follicles and isolated by collagenase digestion as described previously (Marrone \& Hertelendy, 1983a). Viability of the theca cell preparations, as determined by exclusion of $0.01 \%$ trypan blue, was routinely greater than $90 \%$. Cells in each preparation were counted with the aid of haemocytometer and each cell preparation was diluted to a final concentration of $1 \times 10^{6}$ viable cells/ml Medium 199.

\section{Incubations}

Incubations were carried out as described previously (Marrone \& Hertelendy, 1983a). For each cell suspension, $200 \mu \mathrm{l}$ containing $2 \times 10^{5}$ viable cells were pipetted at $4^{\circ} \mathrm{C}$ into $12 \times 75 \mathrm{~mm}$ polystyrene culture tubes that contained Medium 199 and various doses of clomiphene citrate. When LH was used, $0 \cdot 1 \mathrm{mM}$-3-isobutyl-1-methylxanthine (IBMX) was added to the incubation at $0 \mathrm{~h}$ to 
inhibit phosphodiesterase activity. After a $1 \mathrm{~h}$ preincubation, the treatment hormone ( $10 \mathrm{ng} \mathrm{LH}$, $250 \mathrm{ng}$ testosterone, or $250 \mathrm{ng}\left[{ }^{3} \mathrm{H}\right] 17$-hydroxyprogesterone) was added, making a total volume of $1 \mathrm{ml}$ in each tube, and cells were incubated for an additional $3 \mathrm{~h}$.

There were 5 replicate incubation tubes from the same cell preparation per treatment group in each experiment. Incubations were done at $37^{\circ} \mathrm{C}$ in a shaking water bath under air for $3 \mathrm{~h}$ and were terminated by placing the tubes in an ice bath. The incubation tubes were frozen until extraction for radioimmunoassay or HPLC.

\section{Radioimmunoassay}

The incubation media and cells were extracted twice with 2 volumes of diethyl ether. The extraction efficiencies for oestrogen and androstenedione were both $>95 \%$. The extract was evaporated to dryness and redissolved in ethyl alcohol; $75 \%$ of the sample was taken for oestrogen radioimmunoassay and $2-10 \%$ was taken for androstenedione radioimmunoassay.

Details of the radioimmunoassays for oestrogens and androstenedione have been reported previously (Marrone \& Hertelendy, 1985). The oestrogen antiserum (provided by Dr B. V. Caldwell, Yale University) reacts equally well with oestradiol-17 $\beta$ and oestrone and has a $10 \%$ cross-reactivity with oestriol. The inter- and intra-assay coefficients of variation were determined to be $11 \%$ and $5 \%$, respectively, and the sensitivity was $10 \mathrm{pg}$ per tube. The androstenedione antiserum (ANS-22 from Endocrine Sciences, Tarzana, CA) cross-reacts with 1,4-androstadiene3,17-dione $(40 \%), 5 \alpha$ - and $5 \beta$-androstan-3,17-dione $(35 \%)$, androsterone and epiandrosterone $(4 \%)$, androstane $(3 \cdot 5 \%), 5 \alpha$-androstan-3,11,17-trione $(2 \cdot 5 \%)$, and testosterone $(2 \%)$. The coefficients for inter- and intra-assay variation were both $10-11 \%$ and the sensitivity of the assay was $5 \mathrm{pg}$ per tube. Samples from each experiment were analysed in the same radioimmunoassay.

\section{HPLC}

Samples were extracted with diethyl ether as above and evaporated to dryness under a gentle stream of nitrogen in a $45^{\circ} \mathrm{C}$ water bath. The extraction efficiencies of the radioactivity were routinely $>95 \%$. The sample was dissolved in $25 \mu \mathrm{HPLC}$-grade methanol and $20 \mu \mathrm{l}$ were injected into a $5 \mu \mathrm{m}$ reversed-phase $C_{18}$ column (Altex Ultrasphere, $15 \mathrm{~cm} \times 4.6 \mathrm{~mm}$ ). The mobile phase was tetrahydrofuran : methanol : water $(16: 28: 56$ by vol.) at a flow rate of $1 \mathrm{ml} / \mathrm{min}$. Fractions $(0.5 \mathrm{ml})$ were collected for scintillation counting and the profile was visualized by u.v. spectroscopy at $240 \mathrm{~nm}$. Fractions were collected for $30 \mathrm{~min}$ and the total radioactivity in 60 fractions was calculated. All of the metabolites of $\left[{ }^{3} \mathrm{H}\right] 17$-hydroxyprogesterone are eluted within this period. Determination of the production of each steroid metabolite was based on co-elution of radioactivity with a known steroid standard. The radioactivity in each peak was expressed as a percentage of the total radioactivity. Only fractions that had radioactivity twice that of the background level were used for the calculations.

Details of the equipment and separation profile of this solvent system have been reported previously (Marrone \& Hertelendy, 1983b, 1985; Marrone et al., 1985).

\section{Data analysis}

Comparisons between two groups were analysed by Student's $t$-test. Comparisons among more than two groups were analysed by 1-way analysis of variance and Neuman-Keuls post-hoc tests. Probability values of $<0.05$ were considered statistically significant.

\section{Results}

Baseline androstenedione and oestrogen production by theca cells was increased significantly in 


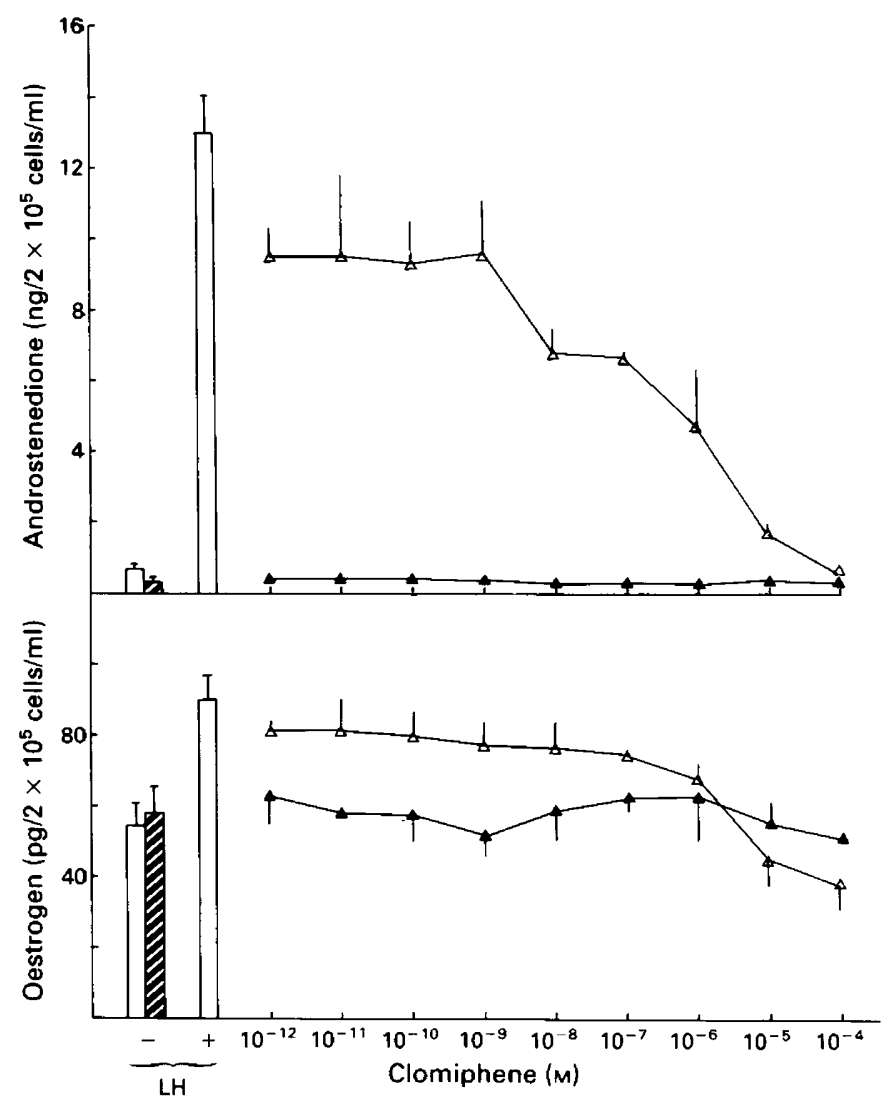

Fig. 1. Dose-response curve of the inhibitory effect of increasing doses of clomiphene on LH-stimulated (open bars and open triangles) and basal production (hatched bar and solid triangles) of androstenedione (top panel) and oestrogen (bottom panel). Theca cells were pretreated for $1 \mathrm{~h}$ with clomiphene, then incubated for $3 \mathrm{~h}$ after the addition of $\mathrm{LH}(50 \mathrm{ng} / \mathrm{ml})$ or $100 \mu \mathrm{l}$ media. The values represent the mean \pm s.e.m. from $3-4$ separate experiments.

response to ovine $\mathrm{LH}(50 \mathrm{ng} / \mathrm{ml})$. When theca cells were preincubated for $1 \mathrm{~h}$ with clomiphene citrate an inhibition of the $\mathrm{LH}$-stimulated androstenedione and oestrogen production was observed (Fig. 1). Clomiphene demonstrated a dose-dependent inhibition of LH-stimulated androstenedione production which was significant statistically from doses of $10^{-8}$ to $10^{-4} \mathrm{M}$-clomiphene. A $50 \%$ inhibition of LH-stimulated androstenedione production was obtained with a dose of $\sim 10^{-8} \mathrm{M}$-clomiphene. There also appeared to be a dose-dependent inhibition of oestrogen production. A significant inhibition of oestrogen production occurred at doses of $10^{-5}$ and $10^{-4} \mathrm{M}$-clomiphene. A $50 \%$ inhibition of LH-stimulated oestrogen production was obtained at a dose of approximately $2 \times 10^{-7} \mathrm{M}$-clomiphene. Basal (unstimulated) production of androstenedione and oestrogen was not consistently influenced by clomiphene.

In an effort to determine which enzymes were inhibited by clomiphene, we examined the effects of clomiphene on conversion of $\left[{ }^{3} \mathrm{H}\right] 17$-hydroxyprogesterone to androstenedione, as a measure of C17-20-lyase activity. Theca cells that had been preincubated with or without $10^{-5} \mathrm{M}$ clomiphene were treated with $250 \mathrm{ng}\left[{ }^{3} \mathrm{H}\right] 17$-hydroxyprogesterone. The major metabolites of 17 -hydroxyprogesterone, as determined previously (Marrone \& Hertelendy, 1985; Marrone et al., 1985), are androstenedione and 17 $\alpha, 20 \beta$-dihydroxy-4-pregnen-3-one. The peaks of radioactivity represented 
by the substrate, andostenedione and 17 $\alpha, 20 \beta$-dihydroxy-4-pregnen-3-one in 5 experiments comprised $94 \pm 0.8 \%$ of the total radioactivity collected in 60 fractions $(30 \mathrm{~min})$. The remaining $5 \%$ of the total radioactivity was distributed in the fractions that eluted before, between, and after these 3 peaks. Theca cells preincubated with clomiphene showed an inhibition of $\left[{ }^{3} \mathrm{H}\right] 17$-hydroxyprogesterone conversion (Fig. 2). Androstenedione production was significantly reduced in those

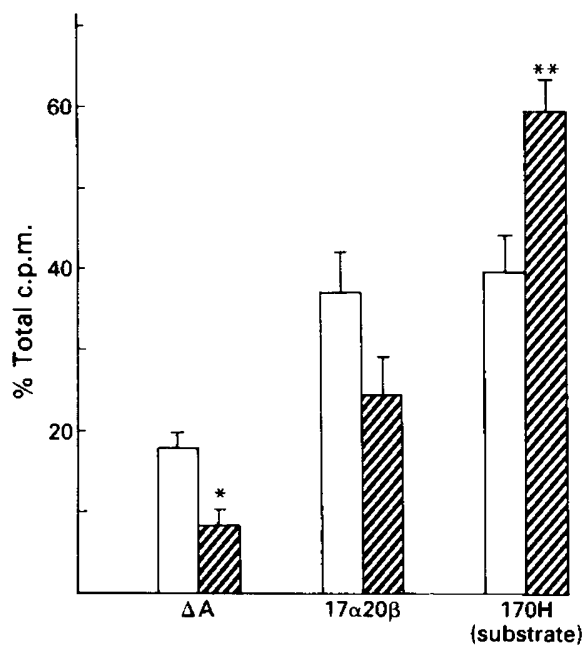

Fig. 2. Effect of clomiphene citrate on conversion of 17-hydroxyprogesterone (17OH) to

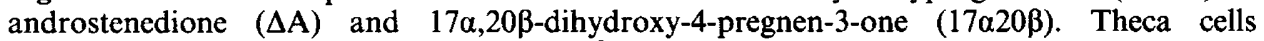
$\left(2 \times 10^{5}\right)$ were pretreated for $1 \mathrm{~h}$ with $10^{-5} \mathrm{M}$-clomiphene (hatched bars) or without clomiphene (open bars). $\left[{ }^{3} \mathrm{H}\right] 17 \mathrm{OH}(250 \mathrm{ng} / \mathrm{ml})$ was added and cells were incubated for an additional $3 \mathrm{~h}$. Steroids were separated by HPLC and the radioactivity in each peak was expressed as the percentage of the total recovered radioactivity. Each bar represents the mean \pm s.e.m. from 5 separate experiments. ${ }^{*} P<0 \cdot 05 ;{ }^{* *} P<0.01$ compared with value without clomiphene.

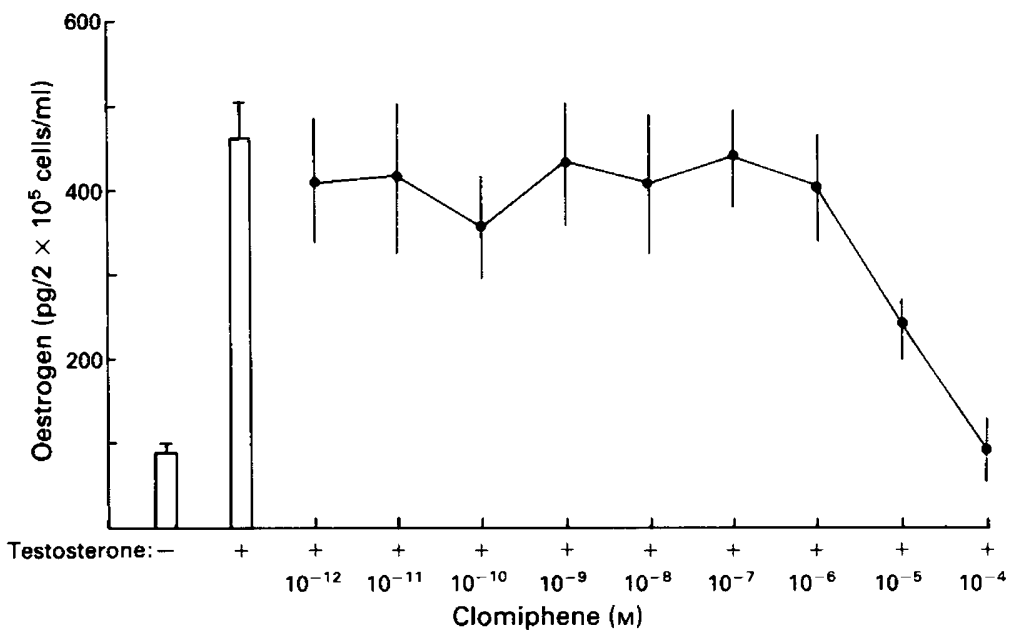

Fig. 3. Dose-response curve of the inhibitory effect of increasing doses of clomiphene on conversion of testosterone to oestrogen. Theca cells were pretreated for $1 \mathrm{~h}$ with clomiphene, then incubated for $3 \mathrm{~h}$ after the addition of testosterone $(250 \mathrm{ng} / \mathrm{ml})$. The values represent the mean \pm s.e.m. of $4-6$ separate experiments. 
cells treated with clomiphene when compared to the control $(P<0.05)$. In addition, a significantly greater amount of $\left[{ }^{3} \mathrm{H}\right] 17$-hydroxyprogesterone remained in clomiphene-pretreated cells $(P<0.01)$. Although there appeared to be a reduction in the formation of $17 \alpha, 20 \beta$-dihydroxy4-pregnen-3-one, this reduction was not statistically significant.

We next examined the effect of clomiphene on the conversion of testosterone to oestrogen by theca cells, an index of aromatase activity. Armstrong (1984) has shown that oestradiol-17 $\beta$ is the only product detected after incubation of hen thecal homogenates with tritiated testosterone. In theca cells pretreated with clomiphene, and then incubated with $250 \mathrm{ng}$ testosterone, conversion of testosterone to oestrogen was inhibited (Fig. 3). Oestrogen production rose significantly after incubation with testosterone. There was no change from control with doses of $10^{-12}$ to $10^{-9} \mathrm{M}$-clomiphene, but a dose-dependent inhibition occurred between $10^{-7}$ and $10^{-4} \mathrm{M}$. Testosterone conversion was significantly inhibited (by $80 \%$ ) at $10^{-4} \mathrm{M}$-clomiphene and, when baseline oestrogen values were subtracted, $50 \%$ inhibition occurred at a dose of $5 \times 10^{-6} \mathrm{M}$-clomiphene.

To assess whether the inhibitory effects of clomiphene could be reversed, theca cells were preincubated with $10^{-5} \mathrm{M}$-clomiphene for $4 \mathrm{~h}$, washed three times, and then incubated with or without $50 \mathrm{ng} \mathrm{LH} / \mathrm{ml}$ for $3 \mathrm{~h}$ in the absence of clomiphene. There were no significant differences in androstenedione production between the clomiphene-pretreated or non-pretreated groups after LH treatment. The mean androstenedione values $\left(\mathrm{pg} / 2 \times 10^{5}\right.$ cells $/ \mathrm{ml}$; mean \pm s.e.m.) of 4 separate experiments were: no clomiphene pretreatment, without LH $(98 \cdot 2 \pm 45 \cdot 3)$ or with $\mathrm{LH}$ $(451 \pm 68 \cdot 0)$; clomiphene pretreatment, without LH (49.8 $\pm 20 \cdot 9)$ or with LH $(360 \pm 74 \cdot 4)$.

\section{Discussion}

This study provides evidence that clomiphene inhibits androstenedione and oestrogen production in hen theca cells in vitro. Clomiphene inhibited LH-stimulated androstenedione and oestrogen production in a dose-dependent manner and, in addition, inhibited both the aromatase and C17-20-lyase enzyme activities. Futhermore, the inhibitory effects of clomiphene on steroidogenesis were reversible. An inhibitory effect of clomiphene on the aromatase activity would obviously result in reduced oestrogen production. Likewise, an inhibitory effect of clomiphene on C17-20lyase activity could contribute indirectly to a reduction in oestrogen production, by limiting the availability of androgen substrate for aromatization to oestrogen.

The inhibitory effects of clomiphene on ovarian steroidogenesis may have two consequences. First, the reduced oestrogen production may enhance LH secretion. It is believed that clomiphene acts at the level of the hypothalamus to displace oestrogen from its receptors, thereby preventing the negative feedback of oestrogen on gonadotrophin release. As a result, LH secretion is stimulated. The hypothalamic action of clomiphene could be enhanced by a direct inhibitory effect of clomiphene on oestrogen production. On the other hand, impaired folliculogenesis may be another consequence of a direct inhibitory effect of clomiphene on ovarian steroidogenesis. Appropriate quantities of oestrogen are needed, with gonadotrophins, to stimulate follicular maturation (see Goodman \& Hodgen, 1983). Therefore, an inhibitory effect of clomiphene on oestrogen biosynthesis could impair the process of folliculogenesis.

There are conflicting reports concerning the effects of clomiphene on oestrogen production. Laufer et al. (1982) reported an inhibition of oestrogen production by clomiphene in vitro by rat preovulatory follicles. In contrast, Zhuang et al. (1982) and Welsh et al. (1984) reported that clomiphene pretreatment in vitro stimulated oestrogen production by rat granulosa cells. In the last two reports, granulosa cells were incubated with clomiphene for 3 days, washed to remove clomiphene, and reincubated with androgen substrate. Oestrogen production was measured after incubation with the androgen substrate, in the absence of clomiphene, and so the 'chronic' effects of clomiphene pretreatment on oestrogen biosynthesis were assessed. During such a long-term exposure, 
there may be opportunities for clomiphene to induce changes in cell metabolism, e.g. induction of steroidogenic enzymes.

In the present study, the 'acute' effects of clomiphene on steroidogenesis were assessed. Oestrogen production was inhibited during a 4-h incubation in the presence of clomiphene. Furthermore, washing the cells after a 4-h exposure to clomiphene reversed the inhibitory effects of clomiphene on steroidogenesis, apparently indicating that this brief exposure to clomiphene did not have a permanent effect on cell metabolism. The differences in experimental protocol between the studies above and the present study may account for the different effects of clomiphene on oestrogen biosynthesis. Furthermore, we cannot rule out that species differences may account for the different effects of clomiphene on oestrogen biosynthesis in the studies discussed above and in the present study.

There are also conflicting reports concerning the effects of clomiphene treatment on oestrogen production in vivo. Marut \& Hodgen (1982) reported that plasma oestrogens decreased during high-dose clomiphene treatment in normally cyclic monkeys despite concurrent elevations of gonadotrophins. Decreased oestrogen concentrations in follicular fluid have also been reported in clomiphene-treated as compared to hMG-treated women (diZerega et al., 1983; Dlugi et al., 1985). However, other reports have described an increase in oestrogen values during clomiphene treatment in monkeys (Littman \& Hodgen, 1985) and women (Wu, 1977; Maxson et al.,1984).

Clearly, in some circumstances clomiphene can exert inhibitory actions on ovarian steroidogenesis. Inhibitory effects of clomiphene in vitro on progesterone biosynthesis have been reported for rat granulosa cells (Welsh et al., 1984), monkey luteal cells (Westfahl \& Resko, 1983), and rat preovulatory follicles (Laufer et al., 1982). In addition to the inhibitory effects reported here on the aromatase and C17-20-lyase activities, clomiphene has been found to inhibit progesterone biosynthesis by an effect on the cholesterol side-chain cleavage enzyme, but not on the $3 \beta$-steroid dehydrogenase enzyme activity, in hen granulosa cells (Sgarlata et al., 1984). Furthermore, an inhibitory effect of clomiphene on cholesterol side-chain cleavage activity was obtained using a mitochondrial preparation of hen granulosa cells (Asem \& Hertelendy, 1985), demonstrating a direct effect of clomiphene on this enzyme. It remains to be determined whether the inhibitory effects of clomiphene on the C17-20-lyase and aromatase enzymes in hen theca cells are mediated by a direct effect of clomiphene on the enzymic reactions. However, since the C17-20-lyase, aromatase, and cholesterol side-chain cleavage enzyme activities are all inhibited by clomiphene, this suggests that clomiphene may act via the same mechanism for each enzyme. The cholesterol side-chain cleavage enzyme, as well as the C17-20-lyase and aromatase enzymes, have in common a cytochrome P-450 as part of their system (Lieberman et al., 1984). The cytochrome P-450 or other similarities in these enzyme systems may be the site of action of clomiphene citrate.

In various mammalian systems, clomiphene has been found to exert both antioestrogenic and oestrogenic effects (see Adashi, 1984). The effect of oestradiol-17 $\beta$ on steroidogenesis by hen theca cells has not been examined and, in the present study, no comparisons were made between the actions of clomiphene and oestradiol- $17 \beta$ on androstenedione and oestrogen production. We are therefore unable to comment on whether or not the effects of clomiphene that we observed are a result of oestrogenic properties of clomiphene in hen theca cells. However, another study has shown that oestradiol-17 $\beta$ and clomiphene have different sites of action on the pathway from cholesterol to progesterone in hen granulosa cells (Sgarlata et al., 1984).

Although we acknowledge that there is a problem in extrapolating in-vitro data from hen ovarian cells to the in-vivo human situation, our results confirm other in-vitro studies done on mammalian tissues which indicate that clomiphene has a direct effect on ovarian steroidogenesis. The present study therefore lends support to the ovary as a secondary site of action in the complex mechanism by which clomiphene induces ovulaton in women.

We thank Dr H. Biellier, University of Missouri, Columbia, Missouri, and Mr D. Stebler, Ralston Purina Research Farms, Gray Summit, Missouri, for generously supplying the experimen- 
tal animals; Ms W. Eleissawy for technical assistance; and Ms Gracia Coffin and Ms Noyola Scott for typing this manuscript. Supported by NIH Grant HD-16623 to B.L.M.

\section{References}

Adashi, E.Y. (1984) Clomiphene citrate: mechanism(s) and site(s) of action-a hypothesis revisited. Fert. Steril. 42, 331-344.

Asem, E.K. \& Hertelendy, F. (1985) Antiestrogens inhibit the cholestrol side-chain cleavage enzyme activity. Biol. Reprod., Suppl. 1, 32, Abstr. 105.

Armstrong, D.G. (1984) Ovarian aromatase activity in the domestic fowl (Gallus domesticus). J. Endocr. 100, $81-86$.

diZerega, G.S., Campeau, J.D., Nakamura, R.N., Ujita, E.L., Lobo, R. \& Marrs, R.P. (1983) Activity of human follicular proteins in spontaneous and induced ovarian cycles. J. clin. Endocr. Metab. 57, 838-846.

Dlugi, A.M., Laufer, N., Botero-Ruiz, W., DeCherney, A.H., Polan, M.L., Haseltine, F.P., Mezer, H.C. \& Behrman, H.R. (1985) Altered follicular development in clomiphene citrate versus human menopausal gonadotropin-stimulated cycles for in vitro fertilization. Fert. Steril. 43, 40-47.

Goodman, A.L. \& Hodgen, G.D. (1983) The ovarian triad of the primate menstrual cycle. Recent Prog. Horm. Res. 39, 1-73.

Laufer, N., Reich, R., Braw, R., Shenker, J.G. \& Tsafriri, A. (1982) Effect of clomiphene citrate on preovulatory rat follicles in culture. Biol. Reprod. 27, 463-471.

Lieberman, S., Greenfield, N.J. \& Wolfson, A. (1984) A heuristic proposal for understanding steroidogenic processes. Endocrine Rev. 5, 128-148.

Littman, B.A. \& Hodgen, G.D. (1985) A comprehensive dose-response study of clomiphene citrate for enhancement of the primate ovarian/menstrual cycle. Fert. Steril. 43, 463-470.

Marrone, B.L. \& Hertelendy, F. (1983a) Steroidogenesis by avian ovarian cells: effects of luteinizing hormone and substrate availability. Am. J. Physiol. 244, E487-E493.

Marrone, B.L. \& Hertelendy, F. (1983b) Steroid metabolism by avian ovarian cells during follicular maturation. Biol. Reprod. 29, 953-962.
Marrone, B.L. \& Hertelendy, F. (1985) Decreased androstenedione production with increased follicular maturation in theca cells from the domestic hen (Gallus domesticus). J. Reprod. Fert. 74, 543-550.

Marrone, B.L., Wiebe, J.P., Buckingham, K.D. \& Hertelendy, F. (1985) Analysis of steroid metabolites produced by theca cells from the adult domestic hen. J. Steroid Biochem. 23, 375-378.

Marut, E.L. \& Hodgen, G.D. (1982) Antiestrogenic action of high-dose clomiphene in primates: pituitary augmentation but with ovarian attenuation. Fert. Steril. 38, 100-104.

Maxson, W.S., Pittaway, D.E., Herbert, C.M., Garner, C.H. \& Wentz, A.C. (1984) Antiestrogenic effect of clomiphene citrate: correlation with serum estradiol concentration. Fert. Steril. 42, 356-359.

Sgarlata, C.S., Mikhail, G. \& Hertelendy, F. (1984) Clomiphene and tamoxifen inhibit progesterone synthesis in granulosa cells: comparisons with estradiol. Endocrinology 114, 2032-2038.

Speroff, L., Glass, R.H. \& Kase, N.G. (1983) Clinical Gynecologic Endrocrinology and Infertility, $\mathrm{pp}$. 523-544. Williams and Wilkins, Baltimore.

Welsh, T.H., Jia, X., Jones, P.B.C., Zhuang, L. \& Hsueh, A.J.W. (1984) Disparate effects of triphenylethylene antiestrogens on estrogen and progestin biosynthesis by cultured rat granulosa cells. Endrocrinology 115, $1275-1282$.

Westfahl, P.K. \& Resko, J.A. (1983) Effects of clomiphene on luteal function in the nonpregnant cynomolgus macaque. Biol. Reprod. 29, 963-969.

Wu, C.H. (1977) Plasma hormones in clomiphene citrate therapy. Obstet. Gynecol. 49, 443-448.

Zhuang, L., Adashi, E.Y. \& Hsueh, A.J.W. (1982) Direct enhancement of gonadotropin-stimulated ovarian estrogen biosynthesis by estrogen and clomiphene citrate. Endocrinology 100, 2219-2221.

Received 3 March 1986 